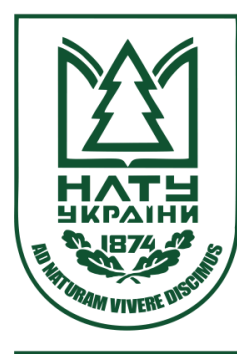

Науковий вісник НЛТУ України

Scientific Bulletin of UNFU

https://nv.nltu.edu.ua

https://doi.org/10.15421/40280722

$@ \bowtie$ Correspondence author

Article received 6.09.2018 p.

Article accepted 26.09.2018 p.

I. O. Ben

удк 674.053:621.93.024.74

beigr@rambler.ru

Ю. І. Озимок, І. О. Бень

Національний лісотехнічний університет Украӥни, м. Львів, Украӥна

\title{
ОСОБЛИВОСТІ ЗАГОСТРЮВАННЯ НОЖІВ ЛУЩИЛЬНИХ І ШПОНОСТРУГАЛЬНИХ ВЕРСТАТІВ
}

Розглянуто проблему загострювання ножів лущильних та шпоностругальних верстатів, яка $\epsilon$ на підприємствах, що спеціалізуються з виготовлення струганого та лущеного шпону. Особливістю загострювання цих ножів $\epsilon$ те, що вони мають широку задню поверхню, малі кути загострення та велику довжину. Велика зона контакту абразивного круга 3 поверхнею ножа призводить до утворення високих температур на поверхні ножа. Внаслідок цього змінюються початкові властивості леза, відбувається його припалювання, виникають великі завусениці, мікротріщини та інші дефекти. Наявні рекомендації щодо раціональних режимів загострення та доводіння дереворізальних інструментів, зокрема лущильних і шпоностругальних ножів, частково вирішують цю проблему, але істотно зменшують продуктивність процесу загострення. Оцінено та проаналізовано конструкції абразивних кругів, які застосовуються для загострення цих ножів. З'ясовано, що для загострення ножів 3 широкою задньою поверхнею потрібно удосконалювати та розробляти новий спеціальний абразивний інструмент, який повною мірою забезпечить якісне загострювання та високу продуктивність процесу. Цей інструмент не повинен потребувати значних змін у конструкції верстата для загострення дереворізальних ножів, повинен бути дешевим і надійним в експлуатації.

Ключові слова: лезо ножа; поверхня ножа; абразивний інструмент; режими загострення; температура на поверхні; продуктивність процесу.

Вступ. Якість поверхні лущеного та струганого шпону є одним з визначальних чинників його сортності та в основному залежить від підготовлення до роботи різальних інструментів лущильних та шпоностругальних верстатів. Загострення цих інструментів, зокрема лущильних та шпоностругальних ножів, є відповідальною операцією, як під час виготовлення цих інструментів, так і під час відновлення їх різальних властивостей після затуплення під час оброблювання деревини. Від якості загострювання інструменту залежить продуктивність праці й вартість оброблення заготівок, період тривкості й величина зношення інструменту.

Висока якість поверхні, гострота різальних кромок, відсутність припалювання, точність геометричних параметрів, забезпечення підвищеної тривкості інструментів можливе лише у разі правильного поєднання характеристики абразивного круга та режимів загострення. При цьому і режими загострення, і характеристика абразивного круга повинні відповідати хімічному складу сталі інструменту, способу охолодження та іншим факторам.

Вирішити це завдання в комплексі доволі важко, позаяк попередньо необхідно з усієї гами абразивних кругів вибрати ті, які будуть найкраще відповідати умовам загострення ножів. Попереднім оцінюванням абразивних кругів можуть слугувати такі показники:

- питома продуктивність абразивних кругів в різних умовах загострення різального інструмента. Цей показник $є$ одним 3 найважливіших для оцінювання абразивного інструмента;

- зношення та затуплення абразивного круга. Вивчення цих показників необхідне для визначення частоти правлення абразивних кругів і обліку їх витрат (Demyanovskii \& Dunaev, 1965).

Виклад основного матеріалу дослідження. Режими загострення ножів (співвідношення величин колової швидкості обертання шліфувального круга $V_{\text {кр. }}$ м/с, швидкості поздовжньої подачі шліфувального круга

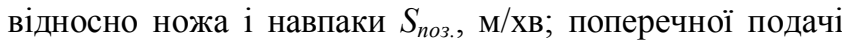
шліфувального круга на глибину врізання $S_{\text {non. }}$ мм) повинні забезпечити задане значення кутових параметрів різальної кромки, необхідну гостроту леза та відсутність завусениць, припалювань, викришувань, шліфувальних тріщин та інших дефектів, зберігання початкових властивостей леза, зумовлених хімічним складом і термічним обробленням сталі, високу чистоту оброблення різальних поверхонь, високу продуктивність і мінімальну витрату абразивного інструмента.

Дотримання наведених вище раціональних режимів дає змогу якісно і з високою продуктивністю процесу загострювати тонкі ножі для фрезування завтовшки до 10 мм, завдовжки до 600 мм, з кутами загострення $\beta=30 \ldots . .50^{\circ}$. Це ножі фрезерних, фугувальних, рейсмусових та стружкових верстатів (Demyanovskii \& Dunaev, 1975).

\section{Інформація про авторів:}

Озимок Юрій Іванович, канд. техн. наук, доцент, кафедра деревообробного обладнання та інструментів. Email: yuriy.ozymok@gmail.com

Бень Ігор Олегович, аспірант, кафедра деревообробного обладнання та інструментів. Email: beigr@rambler.ru

Цитування за ДСТУ: Озимок Ю. І., Бень І. О. Особливості загострювання ножів лущильних і шпоностругальних верстатів. Науковий вісник НЛТУ України. 2018, т. 28, № 7. С. 101-103.

Citation APA: Ozymok, Yu. I., \& Ben, I. O. (2018). Particularities of knifes sharpening of hulling and veneer-shaving machines. Scientific Bulletin of UNFU, 28(7), 101-103. https://doi.org/10.15421/40280722 
Особливістю загострення ножів лущильних і шпоностругальних верстатів є те, що ці ножі мають малі кути загострення $\beta=16 \ldots 18^{\circ}$ і відповідно широку задню поверхню (до 60 мм) та велику довжину (до 2,8 м і більше). Велика зона контакту абразивного круга 3 поверхнею ножа призводить до утворення високих температур на поверхні ножа, внаслідок чого змінюються початкові властивості леза, відбувається його припалювання, виникають великі завусениці, мікротріщини та інші дефекти. Все це негативно впливає як на інструмент, так і на якість оброблення деревини.

Наявні рекомендації щодо раціональних режимів загострення та доводіння дереворізальних інструментів, зокрема лущильних і шпоностругальних ножів, частково вирішують цю проблему, але істотно зменшують продуктивність процесу загострення.

Для зниження температури на поверхні ножа під час загострювання використовують абразивні круги меншої (ніж рекомендують технологічні режими) твердості, але це призводить до значного розмірного зношення м'якого круга, помітно зменшує поперечну подачу в кінці робочого ходу круга, внаслідок чого ніж, що загострюється, має різну ширину за довжиною.

Застосування мастильно-охолоджувальних рідин (MOP) під час загострення ножів неповною мірою дає змогу якісно готувати дереворізальний інструмент до роботи. Конструкції ножезагострювальних верстатів не дають змоги рівномірно охолоджувати поверхню ножа, що шліфується. Причинами виникнення тріщин під час загострення $є$ нерівномірне охолодження та перегрівання. Окрім цього, охолодження водяними розчинами збільшує витрату абразивного інструмента (Demyanovskii \& Dunaev, 1965).

Одним із найефективніших варіантів вирішення цієї проблеми є заміна суцільних абразивних кругів шліфувальними кругами зі вставними сегментами. Такий сегментний шліфувальний круг (рис. 1) насамперед дає змогу економити абразивний матеріал, оскільки суцільний абразивний круг, який повністю не використовується після зношення, замінюють абразивні сегменти, що спеціальними затискачами кріпляться до металевого корпусу.

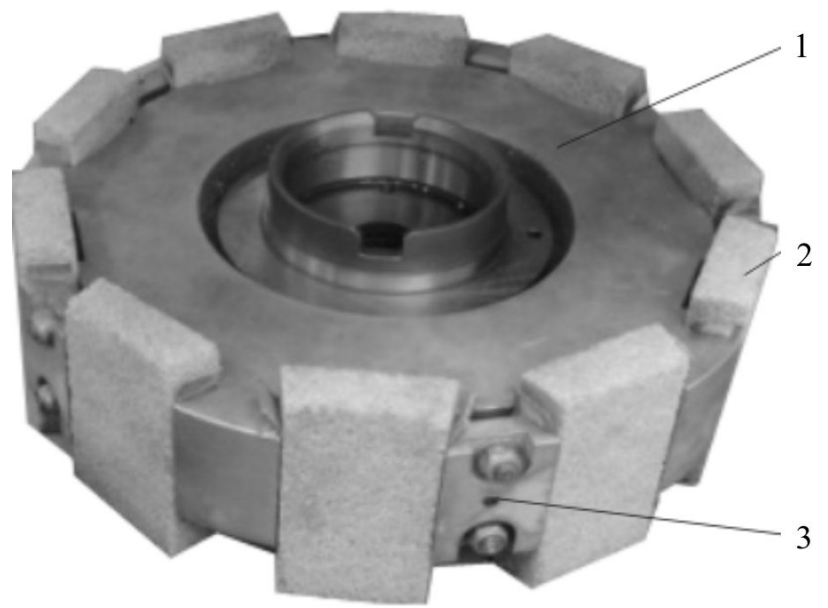

Рис. 1. Шліфувальний круг зі вставними сегментами: 1) корпус; 2) абразивний сегмент (брусок); 3) затискач

Перервна зона контакту сегментного круга зі задньою поверхнею ножа дає змогу частково зменшити температуру нагріву ножа.
Недоліками такої конструкції є:

- складне кріплення сегментних елементів;

- руйнування абразивного шару на ділянках, розміщених на торцевих

- поверхнях різальних виступів;

- наявність огородження;

- складне балансування.

Перервність поверхні сегментного круга і наявність виступаючих конструктивних елементів на збірному перервному колі створює турбулентність руху аеродинамічних потоків повітря. Наявність повітряних аеродинамічних потоків відтискує МОР від обох торців робочих сегментів. Відсутність МОР на окремих ділянках поверхонь, що шліфують, викликає появу місцевих припалювань, що не допустимо під час загострення ножів.

Під час експлуатації такого круга він має нерівномірне зношення сегментів (Loskutov, 1962). Наступним кроком у розвитку абразивного інструмента, саме для загострення ножів, є розроблення багаточашкового абразивного інструмента науковцями кафедри деревообробного обладнання та інструментів НЛТУ України (Ozimok, 2004).

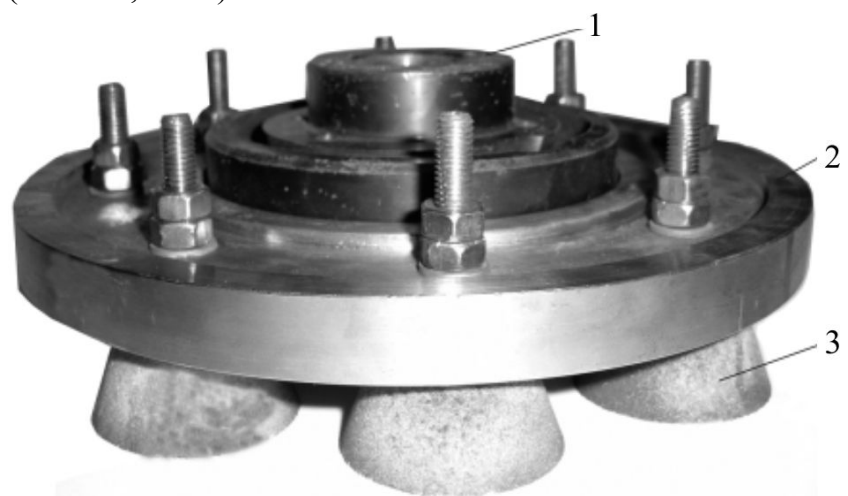

Рис. 2. Багаточашковий абразивний інструмент: 1) фланець; 2) корпус; 3) абразивна чашка

Суть інструмента полягає в тому, що загострення відбувається завдяки восьми чашкам, які симетрично закріплені на корпусі й можуть провертатись навколо власної осі, що значно покращує якість загострення та продуктивність процесу загострювання.

Перевагами багаточашкового інструмента є:

- збільшення довжини різальної поверхні, яка $є$ найбільшою порівняно

- 3 іншими інструментами;

- переривання теплового потоку;

- максимальне використання робочої висоти чашок;

- рівномірне зношення (без правлення);

- встановлення чашок різної зернистості та твердості;

- плавне врізання під час загострення завдяки можливості провертання чашок навколо осі.

Основним недоліком багаточашкового абразивного круга $є$ не контрольованість провертання чашок.

Неробоча частина абразивного матеріалу, яка йде на кріплення чашок багаточашкового абразивного інструмента, у декілька разів менша, ніж у разі використання суцільних чи сегментних кругів. Це дає змогу економити абразивний матеріал. Розрахунки показують, що із залишків суцільного, чи сегментного кругів можна приблизно виготовити комплект малих чашок для нового абразивного інструмента.

Висновок. Проблема загострення ножів із широкою задньою поверхнею є на підприємствах, які спеціалізу- 
ються з виготовлення струганого шпону та фанери, зокрема на ТОВ "Язьм" та на фанерному заводі ТОВ "Свиспан Лімітед". Вивчаючи цю проблему і на основі проведеного аналізу абразивних інструментів, дійшли висновку, що для загострення товстих ножів, а особливо ножів із широкою задньою поверхнею, потрібно удосконалювати та розробляти новий спеціальний абразивний інструмент, який повною мірою забезпечить якісне загострювання та високу продуктивність процесу. Цей інструмент не повинен потребувати значних змін у конструкції верстата для загострення ножів, повинен бути дешевим і надійним в експлуатації.

\section{Перелік використаних джерел}

Demyanovskii, K. I., \& Dunaev, V. D. (1965). Zatochka derevorejuschih instrumentov. Moscow: Lesn. Prom-st, 201 p. [In Russian].

Demyanovskii, K. I., \& Dunaev, V. D. (1975). Zatochka derevorejuschih instrumentov. Moscow: Lesn. Prom-st, 176 p. [In Russian].

Loskutov, V. V. (1962). Shlifovanie metallov. Moscow: Mashgiz, 279 p. [In Russian].

Ozimok, Y. I. (2004). Novii abrazivnii instrument dlya zagostrennya tovstih derevorizalnih nojiv. Scientific Bulletin of UNFU, 14(1), 8184. [In Ukrainian].

Rojkova, D. S. (Ed.). (1978). Konstrukcii nastroika i ekspluataciya oborudovaniya dlya podgotovki i zatochki derevorejuschego instrumenta. Moscow: Lesn. Prom-st, 248 p. [In Russian].

Ю. И. Озимок, И. О. Бень

Национальный лесотехнический университет Украины, г. Львов, Украина

\section{ОСОБЕННОСТИ ЗАТОЧКИ НОЖЕЙ ЛУЩИЛЬНЫХ И ШПОНОСТРОГАЛЬНЫХ СТАНКОВ}

Рассмотрена проблема заточки ножей лущильных и шпонострогальных станков, которая есть на предприятиях, специализирующихся на изготовлении строганного и лущеного шпона. Особенностью заточки этих ножей является то, что они имеют широкую заднюю поверхность, малые углы заточки и большую длину. Большая зона контакта абразивного круга с поверхностью ножа приводит к образованию высоких температур на поверхности ножа. В результате этого изменяются исходные свойства лезвия, происходит его прижигание, возникают большие заусеницы, микротрещины и другие дефекты. Имеющиеся рекомендации по рациональных режимах заточки и доводки дереворежущего инструмента, в частности лущильных и шпонострогальных ножей, частично решают эту проблему, но существенно уменьшают производительность процесса заточки. Оценены и проанализированы конструкции абразивных кругов, применяемых для заточки этих ножей. Выяснено, что для заточки ножей с широкой задней поверхностью нужно совершенствовать и разрабатывать новый специальный абразивный инструмент, который в полной мере обеспечит качественную заточку и высокую производительность процесса. Этот инструмент не должен требовать значительных изменений в конструкции станка для заточки дереворежущих ножей, должен быть дешевым и надежным в эксплуатации.

Ключевые слова: лезвие ножа; поверхность ножа; абразивный инструмент; режимы заточки; температура на поверхности; производительность процесса.

Yu. I. Ozymok, I. O. Ben

Ukrainian National Forestry University, Lviv, Ukraine

\section{PARTICULARITIES OF KNIFES SHARPENING OF HULLING AND VENEER-SHAVING MACHINES}

The problem of knives sharpening of hulling and veneer-shaving machines has been analyzed as it occurs in enterprises specializing on shaved and splintered veneer production. The particularity of such knives sharpening is the fact that they have large back surface, small sharpening angles and big length. The big contact zone of abrasive wheel with knife's surface leads to the increase of temperature on knife's surface. As a result, initial characteristics of the edge change, little burns appear, as well as microcracks and other defects. Current recommendations on rational sharpening regimes of wood-cutting instruments, in particular hulling and veneer-shaving machines, partially solve this problem, and significantly increase sharpening process efficiency. Construction of abradant knives, used for knives sharpening, has been analyzed and assessed. One of the most effective solutions of this problem is the replacement of solid abrasive wheels by the wheels with inserted segments. Interrupted contact zone of segmented abrasive wheel with back knife's surface allows partially decreasing the temperature of the knife. Such segmented abrasive wheel allows first of all saving abrasive material, however has a number of weaknesses. During the use of such wheel a disproportional demolishment of abrasive segments occurs. The next step of the abrasive instrument development for knives sharpening is the elaboration of multi-cups abrasive instruments by the scientists of the Cahir of woodcutting instruments of the UNFU. It consists in the fact that the sharpening occurs due to the abrasive cups fixed on the body in a symmetric way and thus, can turn around their axis, which in turn, improves significantly the quality of sharpening and effectiveness of the process, but also requires some perfection. We have found out that for sharpening knives with a large back surface it is necessary to improve and develop a new special abradant machine, which will fully ensure the quality of sharpening and the high process efficiency. This instrument shouldn't require considerable changes in the construction of the woodcutting knives sharpening machine, but should be less expensive and more reliable in use.

Keywords: knife's edge; abradant machine; sharpening regimes; surface temperature; process efficiency. 